MR. SCOTT D TAGLIAFERRI (Orcid ID : 0000-0003-3669-4131)

DR. PATRICK J OWEN (Orcid ID : 0000-0003-3924-9375)

PROF. JESSICA VAN OOSTERWIJCK (Orcid ID : 0000-0002-8946-4383)

Article type : Review

\title{
Domains of chronic low back pain and assessing treatment effectiveness: A clinical perspective
}

\author{
Mr Scott D Tagliaferri, MSc ClinExPhys ${ }^{1}$ \\ Dr Clint T Miller, $\mathrm{PhD}^{1}$ \\ Dr Patrick J Owen, $\mathrm{PhD}^{1}$ \\ A/Prof Ulrike H Mitchell, $\mathrm{PhD}^{2}$ \\ Prof Helena Brisby, MD $\mathrm{PhD}^{3,4}$ \\ Dr Bernadette Fitzgibbon, $\mathrm{PhD}^{5}$ \\ Dr Hugo Masse-Alarie, $\mathrm{PhD}^{6}$ \\ Dr Jessica Van Oosterwijck, $\mathrm{PhD}^{7-10}$ \\ A/Prof Daniel L Belavy, $\mathrm{PhD}^{1}$
}

1 Deakin University, Institute for Physical Activity and Nutrition, School of Exercise and Nutrition Sciences, Geelong, Australia.

2 Department of Exercise Sciences, Brigham Young University, Provo, Utah, United States of America

This article has been accepted for publication and undergone full peer review but has not been through the copyediting, typesetting, pagination and proofreading process, which may lead to differences between this version and the Version of Record. Please cite this article as doi: 10.1111/PAPR.12846

This article is protected by copyright. All rights reserved 
3 Department of Orthopaedics, Sahlgrenska University Hospital, Gothenburg, Sweden.

4 Department of Orthopaedics, Institute of Clinical Sciences, University of Gothenburg, Gothenburg, Sweden.

5 Central Clinical School, Faculty of Medicine, Nursing and Health Sciences, Monash University, Australia

6 Centre Interdisciplinaire de Recherche en Réadaptation et Integration Sociale (CIRRIS), Université Laval, Québec City, Canada.

7 SPINE Research Unit Ghent, Department of Rehabilitation Sciences, Faculty of Medicine and Health Sciences, Ghent University, Ghent, Belgium.

8 Department of Rehabilitation Sciences and Physiotherapy, Faculty of Medicine and Health Sciences, University of Antwerp, Belgium.

9 Research Foundation - Flanders (FWO), Brussels, Belgium.

10 Pain in Motion international research group, www.paininmotion.be

Corresponding author (whilst in review): Scott Tagliaferri; Deakin University, Institute for Physical Activity and Nutrition, School of Exercise and Nutrition Sciences, 221 Burwood Highway, Burwood, Victoria, 3125, Australia; Tel: +61 39244 6606; Email: scott.tagliaferri@deakin.edu.au

Corresponding author (upon acceptance): A/Prof Daniel L Belavy, PhD; Deakin University, Institute for Physical Activity and Nutrition, School of Exercise and Nutrition Sciences, 221 Burwood Highway, Burwood, Victoria, 3125, Australia. Tel: +61 39244 6606; Fax: +61 39244 6017; E-mail: d.belavy@deakin.edu.au, belavy@gmail.com.

Email addresses: $\quad$ scott.tagliaferri@deakin.edu.au c.miller@deakin.edu.au p.owen@deakin.edu.au rike@byu.edu_helena.brisby@vgregion.se bernadette.fitzgibbon@monash.edu hugo.masse-alarie@fmed.ulaval.ca jessica.vanoosterwijck@ugent.be d.belavy@deakin.edu.au 


\section{ABSTRACT}

Chronic non-specific low back pain (CLBP) is a common clinical condition that has impacts at both the individual and societal level. Pain intensity is a primary outcome used in clinical practice to quantify the severity of CLBP and the efficacy of its treatment, however, pain is a subjective experience that is impacted by a multitude of factors. Moreover, differences in effect sizes for pain intensity are not observed between common conservative treatments, such as spinal manipulative therapy, cognitive behavioural therapy, acupuncture and exercise training. As pain science evolves, the biopsychosocial model is gaining interest in its application for CLBP management. The aim of this paper is to discuss our current scientific understanding of pain and present why additional factors should be considered in conservative CLBP management. In addition to pain intensity, we recommend that clinicians should consider assessing the multidimensional nature of CLBP by including physical (disability, muscular strength and endurance, performance in activities of daily living and body composition), psychological (kinesiophobia, fear-avoidance, pain catastrophizing, pain self-efficacy, depression, anxiety and sleep quality), social (social functioning and work absenteeism) and health-related quality of life measures, depending on what is deemed relevant for each individual. This review also provides practical recommendations to clinicians for the assessment of outcomes beyond pain intensity, including information on how large a change must be for it to be considered 'real' in an individual patient. This information can guide treatment selection when working with an individual with CLBP.

This article is protected by copyright. All rights reserved 


\section{BACKGROUND}

Low back pain (LBP) occurs in $40-85 \%$ of people at some point in their lives ${ }^{1,2}$ and remains the leading cause of reduced function and years lived with disability worldwide. ${ }^{3,4}$ Costs of LBP in the United States of America were shown to be as high as US\$102 billion per year. ${ }^{5}$ Furthermore, a systematic review showed that up to $71 \%$ of individuals with acute LBP are not fully recovered after one year, which may contribute to the costs of the condition. ${ }^{6}$ Chronic LBP (CLBP) is defined as persistent pain for a period of greater than 12 weeks $^{7}$ and affects approximately $20 \%$ of the global population. ${ }^{1}$ In CLBP, $85-90 \%$ of cases have pain that cannot be determined to arise from a definitive pathoanatomic structure or pathology, ${ }^{8}$ and is therefore termed 'non-specific'. ${ }^{9}$ Specific pathologies that cause LBP include infections, metastasis/tumours, osteoporosis, inflammatory disorders, pregnancy, disc herniation and spinal stenosis for the minority of cases. ${ }^{9}$ Regarding types of pain, nociceptive pain arises from threatened or damaged tissue due to the activation of nociceptors, while neuropathic pain is considered to be caused by lesions in the somatosensory nervous system. ${ }^{10}$ Nociceptive and neuropathic causes of pain can originate from specific spinal tissues, with various symptoms, such as the location of pain, numbness and tingling, aggravating and relieving movements, characterising different structures that are affected (e.g. facet joint syndrome, radicular pain and spinal stenosis). ${ }^{11}$ Moreover, nociplastic pain is defined as pain that is disproportionate to the LBP experience, barely related to spine movement or loading, and may or may not related to psychological factors. ${ }^{10}$ To avoid over-diagnosing non-specific CLBP, mechanism-based approaches have been previously suggested and could be followed clinically to help better determine specific nociceptive, neuropathic and nociplastic causes of pain. ${ }^{11,12}$

The management of non-specific CLBP is complicated by multi-dimensional contributions and consequences, including biological, psychological, and social factors. ${ }^{13}$ Conservative approaches, such as spinal manipulative therapy, cognitive behavioural therapy (CBT), pain neuroscience education (PNE), acupuncture and exercise training have shown some success for reducing pain intensity, but the magnitude of their effect remains modest. ${ }^{8}$ However, less emphasis has been placed on physical function, general deconditioning, social isolation and psychological distress, which are known to be compromised in individuals with CLBP. ${ }^{14,15}$ This review aims (i) to discuss the various

This article is protected by copyright. All rights reserved 
factors that may influence pain intensity at the level of the central nervous system (CNS), (ii) to review the multiple domains affected in individuals with CLBP and (iii) propose outcome measures that capture each domain and highlight treatments that may impact these measures.

\section{FACTORS INFLUENCING PAIN}

Pain is a distressing experience that fulfils a protective function essential for survival. It acts as a stimulus to modify behaviours that might be detrimental for tissue integrity and may inform an individual potential or actual tissue damage. ${ }^{16}$ Pain is also a personal, subjective experience that is influenced by genetic, sensory, psychological, emotional, cultural and social factors. ${ }^{16}$ The impact of such contextual factors can be seen in the pathophysiology of perceived acute pain intensity through both peripheral and central processes ${ }^{17}$ Peripherally, nociceptors are depolarized by noxious stimuli (e.g. mechanical, thermal or chemical stimuli) and the information travels through afferent fibres to the dorsal horn of the spinal cord where the signal may undergo modulation before reaching the supraspinal centers. ${ }^{18}$ Multiple brain regions analyse the transmitted information from the periphery with respect to several aspects of the threat (e.g. sensory, awareness, memory, emotional) and depending on the context of the threat, the nociceptive stimuli can be perceived as pain of varying intensity. ${ }^{19}$ For instance, descending pathways can facilitate or inhibit the nociceptive information where descending pain modulation pathways lie. ${ }^{19}$ It is through this mechanism that pain is influenced by top down contextual and dynamic factors (e.g. perceived threat, anxiety, mood, pain-memories) which will determine the resulting pain experience. ${ }^{19}$ In contrast to acute pain where there is a clear protective role, the ongoing experience of pain, definitive of chronic pain conditions, has been suggested to reflect a mismatch between the information on the state of the tissues coming from the peripheral receptors (no acute tissue injury) and the central processing of these information (perceived pain reflecting threat to the tissues). ${ }^{20,21}$ Therefore, pain may move from being an appropriate protective response to becoming overprotective, or results from a heightened state of sensitivity unrelated to tissue pathology. ${ }^{20,21}$ Persistence of this state of enhanced sensitivity of the CNS pain system (in the brain and the spinal cord), can characterize some individuals with CLBP. ${ }^{20}$

This article is protected by copyright. All rights reserved 
Both the peripheral (e.g. nociceptive terminal) and central nervous systems (e.g. spinal cord and brain) can undergo changes that increase their sensitivity (e.g. increasing synaptic strength via longterm potentiation) so that the efficacy of pain processing and protective reactions can be enhanced (Figure 1). ${ }^{20}$ Peripherally, tissues (e.g. intervertebral discs) may be characterized by chronic inflammatory states which can increase nociceptive stimulus strength where synaptic terminals lie in individuals with CLBP. ${ }^{22}$ At the spinal cord, hypersensitivity is increased through pro-inflammatory cytokine release, astrocyte and glial cell activation, which can reduce inhibitory tone and increase synaptic efficiency of ascending nociceptive stimuli (e.g. wind-up mechanism). ${ }^{17}$ The presence of an increased wind-up phenomenon can be evaluated by temporal summation paradigms which use brief repetitive mechanical, thermal or electrical stimuli delivered 1-3 times per second for 5 to 10 seconds. ${ }^{23}$ In the case of increased wind-up mechanism, the temporal pain response is increased from the first to last repetition. ${ }^{24}$ This process within the spinal cord may lead to dynamic changes in second order spinal neurons (e.g. dorsal horn) that could be important for the development and maintenance of central sensitization in CLBP. ${ }^{25}$ It is also believed that central sensitization provides an overarching frame-work to better understand the transition of large-scale brain network activity in acute to chronic pain. ${ }^{26}$ In acute or experimental pain conditions, the brain networks activated are those mostly involved in the processing of the sensory-discriminative nature of pain (e.g. somatosensory cortex), whereas in chronic pain, the activity shifts to the brain networks related to emotional processing (e.g. prefrontal cortex). ${ }^{26}$ These alterations affect the expression and experience of pain as a result of the interplay between physiological (e.g. motor, sensory, autonomic) and psychological (e.g. emotion, cognition, learning) systems. ${ }^{26,27}$ This may explain why behavioural consequences, such as cognitive and memory deficits, exist in people with CLBP. ${ }^{28}$ It is now widely recognised that the intensity of pain can be moderated by psychological factors arising through neurobiological pathways in CLBP, and that these factors influence disability and the response to treatment. ${ }^{29}$ Hence, there is an urgent need to increase the consideration of the multidimensionality of pain in the assessment and treatment of CLBP.

\section{<INSERT FIGURE 1 HERE >}




\section{CURRENT MANAGEMENT OVER FOCUSES ON PAIN INTENSITY}

Clinical treatment guidelines highlight the importance of conservative treatments for individuals with non-specific CLBP. ${ }^{7}$ Conservative interventions, such as PNE $,{ }^{30} \mathrm{CBT},{ }^{31}$ spinal manipulative therapy and various forms of exercise training have shown some success in treating CLBP. ${ }^{32}$ Pain intensity is a common outcome used in the treatment of CLBP in clinical practice and is quantified through selfreported scales, such as the visual analogue scale (VAS). ${ }^{33}$ The VAS most commonly ranges from 0$100 \mathrm{~mm}$, with higher scores indicating a greater pain intensity. ${ }^{33}$ A $20 \mathrm{~mm}$ reduction in pain intensity on the VAS is considered a clinically meaningful change. ${ }^{33}$ Meta-analyses in CLBP show differences in pain intensity do not reach the clinically meaningful threshold when interventions are compared. ${ }^{8}$ Therefore, clinicians and patients should consider basing their choice of conservative management on additional outcomes and mutually agreed goals. ${ }^{34}$ Clinical guidelines in CLBP have moved towards the biopsychosocial model, which may provide clinicians with some insights into additional domains to consider for their patients (Figure 2) ${ }^{35,36}$ Considering that various domains are impacted in CLBP, management could aim to target these outcomes in addition to reducing pain intensity. ${ }^{14}$ Therefore, after the patient is subjectively assessed for risk factors and goals, we propose that clinicians should select outcome measures which are relevant to the person they are treating, that can be easily administered in clinical practice settings and that capture the most important domains of the biopsychosocial model, including physical, psychological and social well-being (Table 1). ${ }^{37}$

$<$ INSERT FIGURE 2 HERE $>$

<INSERT TABLE 1 HERE $>$

\section{MULTIDIMENTIONAL ASSESSMENT OF CHRONIC LOW BACK PAIN}

\section{Biological and Functional Outcomes}

\section{Disability}

Disability due to CLBP is restriction performing activities of daily living (ADLs) and could be a more important reason for individuals to seek care than pain intensity. ${ }^{38} \mathrm{~A}$ meta-analysis showed highly disabled individuals with LBP were eight times more likely to seek care than those with low

This article is protected by copyright. All rights reserved 
disability. ${ }^{38}$ Targeting self-reported disability due to LBP with treatment may help reduce the need to seek professional advice (e.g. physiotherapist, physical therapist or exercise physiologist), ${ }^{39}$ improve the ability of the individual to complete $\mathrm{ADLs}^{38}$ and subsequently reduce health care costs. ${ }^{40}$ Furthermore, clinical guidelines recommend assessing disability should be the highest priority for clinicians. ${ }^{41}$ In addition to LBP disability measures, tools such as the Orebro musculoskeletal pain questionnaire ${ }^{42}$ and the Keele STarT Back Tool ${ }^{43}$ may also be used as an initial screening tool to predict long-term disability. ${ }^{42,43}$ As LBP is a key component contributing to the global burden of disability, self-reported measures of LBP disability and long-term disability prognosis should be considered when assessing the efficacy of CLBP treatments.

\section{Muscular Endurance and Strength}

A meta-analysis suggested muscular endurance and strength to be physical factors associated with LBP. ${ }^{44}$ Individuals with CLBP often have reduced trunk muscle endurance and this may partially relate to the reduced physical capacity in this population. ${ }^{45}$ Cross-sectional research in nurses demonstrated that reduced trunk extension endurance is associated with lower work capacities. ${ }^{46,47}$ Nurses with a full work capacity had a $77 \%$ higher trunk extension endurance compared to those with work modifications due to CLBP. ${ }^{47}$ Furthermore, a systematic review showed functional status and physical demands may be important prognostic factors impeding return to work in those with CLBP. ${ }^{48}$ Even though causality between CLBP and muscle function cannot be determined, improving trunk muscle endurance may provide important training specificity as it closely relates to occupational demands. ${ }^{49}$ Periods of time away from work may lead to deconditioning towards work-related tasks, and therefore may need to be improved to assist with tasks completion and return to work. ${ }^{48}$ Adequate levels of trunk endurance and overall strength appear to assist with ADLs and could be a prognostic factor for return to work, and should be considered in those with CLBP with high physical requirements.

\section{Performance in Activities of Daily Living}

Self-reported measures of disability may not reflect the daily functioning of an individual with CLBP. ${ }^{50}$ Self-report and objective measures of physical function tend to have weak correlations

This article is protected by copyright. All rights reserved 
between each other, ${ }^{51}$ which may relate to the presence of psychological factors, such as depression, causing underestimations on self-report disability measures. ${ }^{52}$ Therefore, assessing self-reported and objective measures may be important to assess functional capacities for those with CLBP. ${ }^{51}$ However, some measures of performance testing (e.g. stair climbing) have been indicated to be poor at differentiating function between people with CLBP and healthy controls. ${ }^{53}$ Furthermore, the ability of these measures to track change over time has been questioned, which may relate to a ceiling effect in those who are not highly disabled. ${ }^{54}$ Performance battery tests could be reserved for those who are highly disabled and cannot perform maximal strength and endurance tests to provide applicable results. ${ }^{54}$ Therefore, performance battery tests could be important to distinguish self-reported and objective physical function.

\section{Adiposity}

Individuals with CLBP often have an increased body fat percentage ${ }^{55}$ and body mass index (BMI), ${ }^{56}$ which may modulate pain through peripheral sensitisation from increased systemic inflammation. ${ }^{57}$ Furthermore, increased fat infiltration of paraspinal musculature (particularly the lumbar multifidus) has been observed in CLBP, ${ }^{58}$ and could be associated with an increased BMI ${ }^{59}$ This association is important as changes to paraspinal muscle composition could compromise function of the muscles that control and support the low back. ${ }^{60,61}$ Whilst the exact mechanisms and causality are unknown, adults with CLBP are more likely to present with obesity related comorbidities, such coronary heart disease. ${ }^{62}$ Individuals with a higher BMI also have greater disability before and after treatment and it may have an important biomechanical influence on functional recovery in those with CLBP. ${ }^{63}$ For example, those with CLBP and a BMI $>27 \mathrm{~kg} / \mathrm{m}^{2}$ have a $16 \%$ greater risk of remaining highly disabled at one-year. ${ }^{64}$ Therefore, body weight, BMI, waist and hip circumference and waist-to-hip ratio could be assessed in those who are overweight or obese patients with CLBP, particularly as an increased $\mathrm{BMI}$ is associated with functional impairments and increased co-morbidities. ${ }^{64}$

\section{Psychological Outcomes}

Kinesiophobia and Fear Avoidance 
Kinesiophobia is defined as the fear of movement ${ }^{65}$ and interferes with the ability to complete ADLs in individuals with CLBP. ${ }^{66}$ A review showed individuals with disabling CLBP and high fearavoidance beliefs had a 2-fold worse prognosis at 1-year compared to low fear-avoidance beliefs. ${ }^{64}$ Furthermore, evidence supports the notion that even in individuals without LBP, movements, such as bending, are feared and considered dangerous. ${ }^{67}$ Given that contextual factors play a role in disability, it is possible that fear of particular movements could add to disability, rather than deconditioning alone and could affect compliance to exercise training. ${ }^{66}$ The removal of fear barriers to movement may therefore be important in promoting resumption of ADLs and reduce disability. ${ }^{64,66}$ Assessing and treating kinesiophobia and fear avoidance during management of CLBP may be important to reduce fear and disability, which could subsequently maximise the participation in ADLs.

\section{Pain Catastrophizing}

Pain catastrophizing is a state of anxiety towards pain and plays an important factor in the fearavoidance model. ${ }^{13}$ Common beliefs are held that the low back is vulnerable and fragile, which may lead to higher catastrophizing when pain occurs in this location. ${ }^{68}$ Individuals with CLBP and high catastrophizing are 56\% more likely to be disabled than those with low catastrophizing. ${ }^{69}$ Furthermore, one study showed that pain catastrophizing may explain more variance in disability $(28 \%)$, when compared to pain intensity $(3 \%) .{ }^{70}$ Even though the regression model used in this study did not include other important factors, such as fear-avoidance, catastrophizing may still be better than pain intensity for explaining disability in individuals with CLBP. ${ }^{70}$ Reducing catastrophic thinking may therefore help reduce the burden of disability in individuals with CLBP which may increase engagement in ADLs.

\section{Pain Self-Efficacy}

Pain self-efficacy is another important psychological outcome to consider when treating patients with CLBP. ${ }^{71}$ Pain self-efficacy reflects an individual's ability to engage with ADLs despite the presence of pain. ${ }^{72}$ Cross-sectional research of individuals with severe disability (measured on the Oswestry disability index) showed lower levels of pain self-efficacy when compared to those with mildmoderate disability. ${ }^{73}$ This may in part explain why individuals with LBP and high pain self-efficacy 
levels are more likely to return to work. ${ }^{74}$ Pain self-efficacy also tends to mediate the relationship between pain and disability more than fear-avoidance. ${ }^{71}$ As the course of pain intensity in CLBP fluctuates, it may be important to understand how the individual psychologically deals with times of high pain intensity and if they continue to engage in normal activities. ${ }^{75}$ Therefore, as pain selfefficacy can be used to understand how individuals cope with setbacks (e.g. flare-ups) it forms a potential outcome for treating individuals with CLBP.

\section{Depression and Anxiety}

Longitudinal evidence of large samples sizes (pooled $n=2,767$ ) showed a bidirectional relationship between LBP, depression and anxiety. ${ }^{76,77}$ Furthermore, an epidemiological study in 190,593 community-dwelling adults showed a higher prevalence of depression (25\%) and anxiety (19\%) in people with CLBP. ${ }^{78}$ Mental health disorders may partially explain disability in those with CLBP ${ }^{79}$ and could be an important factor for recovery from disabling back pain. ${ }^{64}$ Furthermore, a systematic review showed that depression and anxiety are barriers for treatment adherence in various chronic pain conditions. ${ }^{80}$ Given the higher prevalence of these conditions in individuals with CLBP, improving mental health may subsequently improve treatment adherence and effectiveness. ${ }^{80}$ For individuals with CLBP reporting symptoms of depression and anxiety, assessing and treating these factors may be important for functional recovery.

\section{Sleep Quality}

Impairments to sleep are commonly reported in individuals with CLBP, with a 55\% decrease in sleep quality observed in this population following an increase in pain. ${ }^{81}$ An epidemiological study showed CLBP patients to have a 2.4-fold increased risk of sleep problems. ${ }^{78}$ Furthermore, there is the potential for there to be a bidirectional relationship between pain and sleep quality in individuals with CLBP. ${ }^{82}$ For example, every 0.49 point (out of 10 on a visual analogue scale) decrease is sleep quality, pain upon waking is one-point higher on the VAS. ${ }^{82}$ Meanwhile, for every one-point increase in average day time pain intensity, there is a 0.20 point decrease in sleep quality ${ }^{82}$ Moreover, disturbances to the quality of sleep in individuals with CLBP is moderately correlated $(r=0.42)$ to physical disability ${ }^{83}$ Therefore, disability in this population may be partially related to sleep quality. 
Assessing and restoring sleep quality in those with CLBP who report sleep impairments may be important for reducing disability in this population.

\section{Social Outcomes}

\section{Social Functioning}

Social functioning is considered as the individual's ability to engage in social activities. ${ }^{84} \mathrm{~A}$ qualitative review showed that individuals living with LBP felt they struggled to meet social expectations, which may subsequently impact the social identity of the invididual. ${ }^{85}$ Particularly, engagement in domestic chores, valued recreational activities and work tasks are impacted in those with CLBP. ${ }^{85}$ A previous study showed significant, albeit modest, correlation between individual perceptions of physical health and level of social interaction. ${ }^{86}$ This is important as the context of the social environment may also be a potential mediator of pain and subsequent social impairment. ${ }^{87}$ It is possible this may lead to a loss of social identity and the perceptions of ability to perform tasks at home and work, therefore contributing to functional impairments, ${ }^{86}$ decreases in the health-related quality of life ${ }^{88}$ and presence of comorbidities, such as depression. ${ }^{89}$ If the client reports limitations to their social functioning, it is important to assess the impact of CLBP on social functioning to help reduce the risk of the individual losing their social identity.

\section{Work Absenteeism}

Disability from LBP is highest amongst those of working age and tends to decline after retirement age (i.e. 55yrs). ${ }^{13}$ Accommodating work-related outcomes may be important at both an individual and economic level, as majority of the costs of LBP come from indirect sources, such as work absenteeism and early retirement. ${ }^{90}$ Previous work absenteeism due to LBP has been linked to a $31 \%$ less chance of functional recovery in those with CLBP, ${ }^{91}$ which may be associated with early retirement from low back issues. ${ }^{92}$ Early retirement due to LBP may lead to lower net wealth than counterparts who do not retire early, causing greater financial stress later in life..$^{92}$ Reducing work absenteeism may be an important outcome measure to maximise functional work limitations and reduce the financial stress of individuals who become work disabled. 


\section{Health-related Quality of Life}

Quality of life is the self-evaluation of well-being and functioning by an individual ${ }^{93}$ CLBP has a negative impact on the quality of life of an individual, particularly through perceptions of physical and mental health. ${ }^{88} \mathrm{~A}$ cross-sectional study in 1,208 pain clinic patients showed that individuals with CLBP had a lower quality of life compared to other chronic pain conditions, such as headaches and neck pain, as well as the general population. ${ }^{88}$ Importantly, improvements in quality of life may be dictated to a greater extent by disability and psychological improvements rather than pain intensity. ${ }^{94,95}$ Common quality of life questionnaires can measure varying domains including physical functioning, role limitations due to physical functioning, bodily pain, general health perception, vitality, social functioning, role limitations due to emotional and mental health. ${ }^{96}$ Measuring quality of life may provide insight into varying domains impacted in the individual and therefore allow targeted treatment to improve these. Pain intensity is not synonymous with the quality of life, therefore, assessing domains of quality of life may be important to discriminate treatment approaches and determine important client related goals in those with CLBP.

\section{Integrating technological advances into outcomes}

Technological advances should be considered by clinicians for the provision of outcomes during treatment of CLBP. Self-management applications have been used in CLBP, which could be used as outcomes or to attain intervention adherence. ${ }^{97}$ For example, fitness applications (with or without the use of a smartwatch) could be used to track daily physical activity and exercise progressions, ${ }^{98}$ weight loss, ${ }^{99}$ diet and nutrition, ${ }^{100}$ mood ${ }^{101}$ and sleep quality. ${ }^{102}$ The utility of such applications could be used to quantify day-to-day or week-to-week results of various outcomes, rather than being solely collected at periods where the individual reports back to their health care provider. ${ }^{103}$ As multiple areas can be assessed, it is important to determine the most relevant outcome domain for the individual when selecting which application to utilise. ${ }^{103}$ Therefore, these technologies should be considered alongside standard clinical measures (e.g. functional tests and questionnaires) to potentially provide better tracking of outcome measures for individuals with CLBP.

\section{Outcome selection should be individualised for the patient}


Multiple domains and outcomes can be assessed in a patient with CLBP, therefore the clinician should select outcomes based off impacted areas and additional goals. ${ }^{104}$ Clinicians should engage in dialogue and listen to their patients to identify the most important clinical outcome measures, outside of pain intensity, for their patient. ${ }^{104}$ This may assist with determining the most appropriate intervention to reduce disability and improve quality of life in this population. ${ }^{104}$ Furthermore, technological advances (e.g. mobile applications) could be used to assist in the provision of outcome measures and could be utilised for an individual with CLBP. ${ }^{103}$ Given the wide range of measures possible to target, pending what outcomes are deemed relevant for the individual with CLBP, a multidisciplinary approach may best be utilised to maximise outcomes.

\section{A MULTIDISCIPLINARY APPROACH}

A multidisciplinary approach is the collaboration of multiple clinicians and should be considered for those with CLBP, as some outcomes require specific interventions. ${ }^{105}$ For example, a psychologist may be best placed to provide interventions to improve psychosocial health through changing cognitions and behaviours. ${ }^{105}$ Moreover, physiotherapists and exercise physiologists should be considered for improving physical capacity through exercise training, while an occupational therapist could be used to target workplace and daily living contributors to pain and disability. ${ }^{105}$ Dietary advice for individuals with CLBP should be delivered by a dietitian, if adiposity is identified as a relevant outcome. ${ }^{106}$ Pain physicians can coordinate the medical management of the patient to best determine which clinicians to utilise, and formalise communication between each. ${ }^{105}$ Importantly, in private practice settings, clinicians should identify the specific outcomes relevant to their patient and refer on to the appropriate clinician to target these outcomes as necessary. Ultimately, clinicians should engage with a range of health care professionals, including those aforementioned, to establish a multidisciplinary care team capable of providing best-practice management of CLBP.

\section{CONCLUSIONS}

CLBP is a common condition that has a large societal and individual burden. Pain reduction is an important outcome for conservative management of people with CLBP, however it should not be the only outcome of interest in clinical practice. The multidimensional nature of CLBP suggests that 
various factors play a role in pain and disability and that different individuals may be impacted at different levels for each domain. This suggests that the CLBP management should be adapted to the individual as CLBP can have a detrimental impact on physical, psychological and social health. Clinicians should engage in dialogue with patients to determine what aspects of these domains are of the most concern. Rather than solely focusing on pain intensity, treatment of CLBP should address alternative outcomes that are mutually agreed by the clinician and patient. Therefore, in line with the biopsychosocial model, we recommend that clinicians should consider assessing a broad range of physical, psychological, social, and health-related quality of life measures in patients with CLBP. We recommend, at a minimum, clinicians should include the Oswestry Disability Index (physical), Pain Catastrophizing Scale or Tampa Scale of Kinesiophobia (psychological), PROMIS social functioning (social) and the SF-12 (health-related quality of life), with additional measures to be based on what is deemed relevant for the individual patient. Ultimately, this will enable enhanced clinical decision making and lead to improved clinical outcomes specific to the individual patient. 


\section{Acknowledgements and Disclosures}

Jessica Van Oosterwijck is a Postdoctoral Fellow funded by the Research Foundation - Flanders (FWO) (grant number 12L5619N). No other disclosures to acknowledge.

\section{Funding sources}

No funding to report

\section{Author contributions:}

SDT - Preparation of manuscript, approval of manuscript.

CTM - Revision of manuscript, approval of manuscript.

PJO - Revision of manuscript, approval of manuscript.

UHM - Revision of manuscript, approval of manuscript.

HB - Revision of manuscript, approval of manuscript.

BF - Revision of manuscript, approval of manuscript.

HMA - Revision of manuscript, approval of manuscript.

JVO - Revision of manuscript, approval of manuscript.

DLB - Revision of manuscript, approval of manuscript. 


\section{REFERENCES}

1. Hoy D, Bain C, Williams G, et al. A systematic review of the global prevalence of low back pain. Arthritis \& Rheumatology. 2012;64(6):2028-2037.

2. Andersson GB. Epidemiological features of chronic low-back pain. The Lancet. 1999;354(9178):581-585.

3. Vos T, Flaxman AD, Naghavi M, et al. Years lived with disability (YLDs) for 1160 sequelae of 289 diseases and injuries 1990-2010: A systematic analysis for the global burden of disease study 2010. The Lancet. 2012;380(9859):2163-2196.

4. Murray CJ, Vos T, Lozano R, et al. Disability-adjusted life years (DALYs) for 291 diseases and injuries in 21 regions, 1990-2010: A systematic analysis for the Global Burden of Disease Study 2010. The Lancet. 2013;380(9859):2197-2223.

5. Martin BI, Deyo RA, Mirza SK, et al. Expenditures and health status among adults with back and neck problems. JAMA. 2008;299(6):656-664.

6. Itz CJ, Geurts J, Van Kleef M, Nelemans P. Clinical course of non - specific low back pain: A systematic review of prospective cohort studies set in primary care. European Journal of Pain. 2013;17(1):5-15.

7. Qaseem A, Wilt TJ, McLean RM, Forciea MA. Noninvasive treatments for acute, subacute, and chronic low back pain: A clinical practice guideline from the American College of Physicians. Annals of Internal Medicine. 2017;166(7):514-530.

8. Maher C, Underwood M, Buchbinder R. Non-specific low back pain. The Lancet. 2017;389(10070):736-747.

9. Balagué F, Mannion AF, Pellisé F, Cedraschi C. Non-specific low back pain. The Lancet. 2012;379(9814):482-491.

10. Kosek E, Cohen M, Baron R, et al. Do we need a third mechanistic descriptor for chronic pain states? Pain. 2016;157(7):1382-1386.

11. Allegri M, Montella S, Salici F, et al. Mechanisms of low back pain: A guide for diagnosis and therapy. F1000Research. 2016;5.

This article is protected by copyright. All rights reserved 
12. Nijs J, Apeldoorn A, Hallegraeff $\mathrm{H}$, et al. Low back pain: Guidelines for the clinical classification of predominant neuropathic, nociceptive, or central sensitization pain. Pain Physician. 2015;18(3):E333-346.

13. Hartvigsen J, Hancock MJ, Kongsted A, et al. What low back pain is and why we need to pay attention. The Lancet. 2018;6736(18):1-12.

14. Verbunt JA, Smeets RJ, Wittink HM. Cause or effect? Deconditioning and chronic low back pain. Pain. 2010;149(3):428-430.

15. Snelgrove S, Liossi C. Living with chronic low back pain: A metasynthesis of qualitative research. Chronic Illness. 2013;9(4):283-301.

16. Williams A, Craig KD. Updating the definition of pain. Pain. 2016;157(11):2420-2423.

17. D'Mello R, Dickenson A. Spinal cord mechanisms of pain. British Journal of Anaesthesia. 2008;101(1):8-16.

18. Gatchel RJ, Peng YB, Peters ML, Fuchs PN, Turk DC. The biopsychosocial approach to chronic pain: Scientific advances and future directions. Psychological Bulletin. 2007;133(4):581.

19. Voscopoulos C, Lema M. When does acute pain become chronic? British Journal of Anaesthesia. 2010;105:69-85.

20. Baliki MN, Apkarian AV. Nociception, pain, negative moods, and behavior selection. Neuron. 2015;87(3):474-491.

21. Moseley GL, Vlaeyen JW. Beyond nociception: The imprecision hypothesis of chronic pain. Pain. 2015;156(1):35-38.

22. Rustenburg CM, Emanuel KS, Peeters M, Lems WF, Vergroesen PPA, Smit TH. Osteoarthritis and intervertebral disc degeneration: Quite different, quite similar. Jor Spine. 2018;1(4):e1033.

23. Arendt-Nielsen L, Brennum J, Sindrup S, Bak P. Electrophysiological and psychophysical quantification of temporal summation in the human nociceptive system. European Journal of Applied Physiology and Occupational Physiology. 1994;68(3):266-273. 
24. Staud R, Vierck CJ, Cannon RL, Mauderli AP, Price DD. Abnormal sensitization and temporal summation of second pain (wind-up) in patients with fibromyalgia syndrome. Pain. 2001;91(1-2):165-175.

25. Meacham K, Shepherd A, Mohapatra DP, Haroutounian S. Neuropathic pain: central vs. peripheral mechanisms. Current Pain and Headache Reports. 2017;21(6):28.

26. Hashmi JA, Baliki MN, Huang L, et al. Shape shifting pain: Chronification of back pain shifts brain representation from nociceptive to emotional circuits. Brain. 2013;136(9):2751-2768.

27. Kucyi A, Davis KD. The dynamic pain connectome. Trends in Neurosciences. 2015;38(2):8695.

28. Simons LE, Elman I, Borsook D. Psychological processing in chronic pain: A neural systems approach. Neuroscience \& Biobehavioral Reviews. 2014;39:61-78.

29. Hill JC, Fritz JM. Psychosocial influences on low back pain, disability, and response to treatment. Physical Therapy. 2011;91(5):712-721.

30. Clarke CL, Ryan CG, Martin DJ. Pain neurophysiology education for the management of individuals with chronic low back pain: A systematic review and meta-analysis. Manual Therapy. 2011;16(6):544-549.

31. Lamb SE, Hansen Z, Lall R, et al. Group cognitive behavioural treatment for low-back pain in primary care: A randomised controlled trial and cost-effectiveness analysis. The Lancet. 2010;375(9718):916-923.

32. van Middelkoop M, Rubinstein SM, Verhagen AP, Ostelo RW, Koes BW, van Tulder MW. Exercise therapy for chronic nonspecific low-back pain. Best Practice \& Research Clinical Rheumatology. 2010;24(2):193-204.

33. Mannion AF, Balagué F, Pellisé F, Cedraschi C. Pain measurement in patients with low back pain. Nature Reviews Rheumatology. 2007;3(11):610.

34. Booth J, Moseley GL, Schiltenwolf M, Cashin A, Davies M, Hübscher M. Exercise for chronic musculoskeletal pain: A biopsychosocial approach. Musculoskeletal Care. 2017;15(4):413-421.

35. Pillastrini P, Gardenghi I, Bonetti F, et al. An updated overview of clinical guidelines for chronic low back pain management in primary care. Joint Bone Spine. 2012;79(2):176-185.

This article is protected by copyright. All rights reserved 
36. O'Sullivan P. It's time for change with the management of non-specific chronic low back pain. British Journal of Sports Medicine. 2011;46(4):224-227.

37. Pincus T, Kent P, Bronfort G, Loisel P, Pransky G, Hartvigsen J. Twenty-five years with the biopsychosocial model of low back pain — is it time to celebrate? A report from the twelfth international forum for primary care research on low back pain. Spine. 2013;38(24):21182123.

38. Ferreira ML, Machado G, Latimer J, Maher C, Ferreira PH, Smeets RJ. Factors defining careseeking in low back pain: A meta analysis of population based surveys. European Journal of Pain. 2010;14(7):747.

39. Exercise \& Sports Science Australia. What is an accredited exercise physiologist? 2019; https://www.essa.org.au/Public/Consumer_Information/What_is_an_Accredited_Exercise_Ph ysiologist_aspx.

40. Burton AK. United kingdom back pain exercise and manipulation (UK BEAM) randomised trial: Cost effectiveness of physical treatments for back pain in primary care. The BMJ. 2004;329(7479):1381-1385.

41. Chiarotto A, Boers M, Deyo RA, et al. Core outcome measurement instruments for clinical trials in nonspecific low back pain. Pain. 2018;159(3):481-495.

42. Linton SJ, Boersma K. Early identification of patients at risk of developing a persistent back problem: The predictive validity of the Örebro Musculoskeletal Pain Questionnaire. The Clinical Journal of Pain. 2003;19(2):80-86.

43. Hill JC, Dunn KM, Lewis M, et al. A primary care back pain screening tool: Identifying patient subgroups for initial treatment. Arthritis Care \& Research. 2008;59(5):632-641.

44. Taylor JB, Goode AP, George SZ, Cook CE. Incidence and risk factors for first-time incident low back pain: A systematic review and meta-analysis. The Spine Journal. 2014;14(10):22992319.

45. Ledoux É, Dubois J-D, Descarreaux M. Physical and psychosocial predictors of functional trunk capacity in older adults with and without low back pain. Journal of Manipulative \& Physiological Therapeutics. 2012;35(5):338-345.

This article is protected by copyright. All rights reserved 
46. Rissanen A, Heliovaara M, Alaranta H, et al. Does good trunk extensor performance protect against back-related work disability? Journal of Rehabilitation Medicine. 2002;34(2):62-66.

47. Denis S, Shannon HS, Wessel J, Stratford P, Weller I. Association of low back pain, impairment, disability and work limitations in nurses. Journal of Occupational Rehabilitation. 2007;17(2):213-226.

48. Steenstra IA, Munhall C, Irvin E, et al. Systematic review of prognostic factors for return to work in workers with sub acute and chronic low back pain. Journal of Occupational Rehabilitation. 2017;27(3):369-381.

49. Halim I, Omar AR, Saman AM, Othman I. Assessment of muscle fatigue associated with prolonged standing in the workplace. Safety and Health at Work. 2012;3(1):31-42.

50. Smeets RJ, Van Geel AC, Kester AD, André Knottnerus J. Physical capacity tasks in chronic low back pain: What is the contributing role of cardiovascular capacity, pain and psychological factors? Disability and Rehabilitation. 2007;29(7):577-586.

51. Brouwer S, Dijkstra P, Stewart R, Göeken L, Groothoff J, Geertzen J. Comparing self-report, clinical examination and functional testing in the assessment of work-related limitations in patients with chronic low back pain. Disability and Rehabilitation. 2005;27(17):999-1005.

52. Wittink H, Rogers W, Sukiennik A, Carr DB. Physical functioning: Self-report and performance measures are related but distinct. Spine. 2003;28(20):2407-2413.

53. Pfingsten M, Lueder S, Luedtke K, Petzke F, Hildebrandt J. Significance of physical performance tests for patients with low back pain. Pain Medicine. 2014;15(7):1211-1221.

54. Denteneer L, Van Daele U, Truijen S, De Hertogh W, Meirte J, Stassijns G. Reliability of physical functioning tests in patients with low back pain: A systematic review. The Spine Journal. 2018;18(1):190-207.

55. Hodselmans AP, Dijkstra PU, Geertzen JH, van der Schans CP. Nonspecific chronic low back pain patients are deconditioned and have an increased body fat percentage. International Journal of Rehabilitation Research. 2010;33(3):268-270.

56. Heuch I, Hagen K, Heuch I, Nygaard Ø, Zwart J-A. The impact of body mass index on the prevalence of low back pain: The HUNT study. Spine. 2010;35(7):764-768.

This article is protected by copyright. All rights reserved 
57. Walsh TP, Arnold JB, Evans AM, Yaxley A, Damarell RA, Shanahan EM. The association between body fat and musculoskeletal pain: A systematic review and meta-analysis. $B M C$ Musculoskeletal Disorders. 2018;19(1):233.

58. Goubert D, Van Oosterwijck J, Meeus M, Danneels L. Structural changes of lumbar muscles in non-specific low back pain: A systematic review. Pain Physician. 2016;19(7):985-1000.

59. Fortin M, Videman T, Gibbons L, Battie M. Paraspinal muscle morphology and composition. Medicine \& Science in Sports \& Exercise. 2014;46(5):893-901.

60. Ranger TA, Cicuttini FM, Jensen TS, et al. Is the size and composition of the paraspinal muscles associated with low back pain? A systematic review. The Spine Journal. 2017;17:1729-1748.

61. Schlaeger S, Inhuber S, Rohrmeier A, et al. Association of paraspinal muscle water-fat MRIbased measurements with isometric strength measurements. European Radiology. 2018:1-10.

62. Fernandez M, Ordoñana JR, Hartvigsen J, et al. Is chronic low back pain associated with the prevalence of coronary heart disease when genetic susceptibility is considered? A co-twin control study of Spanish twins. PLOS One. 2016;11(5):1-15.

63. Wertli MM, Held U, Campello M, Weiner SS. Obesity is associated with more disability at presentation and after treatment in low back pain but not in neck pain: Findings from the OIOC registry. BMC Musculoskeletal Disorders. 2016;17(1):140.

64. Chou R, Shekelle P. Will this patient develop persistent disabling low back pain? JAMA. 2010;303(13):1295-1302.

65. Wertli MM, Rasmussen-Barr E, Weiser S, Bachmann LM, Brunner F. The role of fear avoidance beliefs as a prognostic factor for outcome in patients with nonspecific low back pain: A systematic review. The Spine Journal. 2014;14(5):816-836.

66. Rainville J, Smeets RJ, Bendix T, Tveito TH, Poiraudeau S, Indahl AJ. Fear-avoidance beliefs and pain avoidance in low back pain - translating research into clinical practice. The Spine Journal. 2011;11(9):895-903.

67. Caneiro J, O'Sullivan P, Lipp OV, et al. Evaluation of implicit associations between back posture and safety of bending and lifting in people without pain. Scandinavian Journal of Pain. 2018.

This article is protected by copyright. All rights reserved 
68. Singh G, Newton C, O'Sullivan K, Soundy A, Heneghan NR. Exploring the lived experience and chronic low back pain beliefs of english-speaking Punjabi and white British people: A qualitative study within the NHS. BMJ Open. 2018;8(2):1-11.

69. Wertli MM, Eugster R, Held U, Steurer J, Kofmehl R, Weiser S. Catastrophizing - a prognostic factor for outcome in patients with low back pain: A systematic review. The Spine Journal. 2014;14(11):2639-2657.

70. Kovacs FM, Seco J, Royuela A, Peña A, Muriel A. The correlation between pain, catastrophizing, and disability in subacute and chronic low back pain: A study in the routine clinical practice of the Spanish National Health Service. Spine. 2011;36(4):339-345.

71. Costa LdCM, Maher CG, McAuley JH, Hancock MJ, Smeets RJ. Self - efficacy is more important than fear of movement in mediating the relationship between pain and disability in chronic low back pain. European Journal of Pain. 2011;15(2):213-219.

72. Nicholas MK. The pain self-efficacy questionnaire: Taking pain into account. European Journal of Pain. 2007;11(2):153-163.

73. de Moraes Vieira ÉB, de Góes Salvetti M, Damiani LP, de Mattos Pimenta CA. Self-efficacy and fear avoidance beliefs in chronic low back pain patients: Coexistence and associated factors. Pain Management Nursing. 2014;15(3):593-602.

74. Richard S, Dionne CE, Nouwen A. Self-efficacy and health locus of control: Relationship to occupational disability among workers with back pain. Journal of Occupational Rehabilitation. 2011;21(3):421-430.

75. Kongsted A, Kent P, Axen I, Downie AS, Dunn KM. What have we learned from ten years of trajectory research in low back pain? BMC Musculoskeletal Disorders. 2016;17(1):220.

76. Gerrits MM, van Oppen P, van Marwijk HW, Penninx BW, van der Horst HE. Pain and the onset of depressive and anxiety disorders. Pain. 2014;155(1):53-59.

77. Gerrits MM, van Marwijk HW, van Oppen P, van der Horst H, Penninx BW. Longitudinal association between pain, and depression and anxiety over four years. Journal of Pychosomatic Research. 2015;78(1):64-70.

This article is protected by copyright. All rights reserved 
78. Stubbs B, Koyanagi A, Thompson T, et al. The epidemiology of back pain and its relationship with depression, psychosis, anxiety, sleep disturbances, and stress sensitivity: Data from 43 low-and middle-income countries. General Hospital Psychiatry. 2016;43:63-70.

79. Hung C-I, Liu C-Y, Fu T-S. Depression: An important factor associated with disability among patients with chronic low back pain. The International Journal of Psychiatry in Medicine. 2015;49(3):187-198.

80. Jack K, McLean SM, Moffett JK, Gardiner E. Barriers to treatment adherence in physiotherapy outpatient clinics: A systematic review. Manual Therapy. 2010;15(3):220-228.

81. Marin R, Cyhan T, Miklos W. Sleep disturbance in patients with chronic low back pain. American Journal of Physical Medicine \& Rehabilitation. 2006;85(5):430-435.

82. Alsaadi SM, McAuley JH, Hush JM, et al. The bidirectional relationship between pain intensity and sleep disturbance/quality in patients with low back pain. The Clinical Journal of Pain. 2014;30(9):755-765.

83. McCracken LM, Iverson GL. Disrupted sleep patterns and daily functioning in patients with chronic pain. Pain Research and Management. 2002;7(2):75-79.

84. Chiarotto A, Deyo RA, Terwee CB, et al. Core outcome domains for clinical trials in nonspecific low back pain. European Spine Journal. 2015;24(6):1127-1142.

85. Froud R, Patterson S, Eldridge S, et al. A systematic review and meta-synthesis of the impact of low back pain on people's lives. BMC Musculoskeletal Disorders. 2014;15(1):50.

86. Takeyachi Y, Konno S-i, Otani K, et al. Correlation of low back pain with functional status, general health perception, social participation, subjective happiness, and patient satisfaction. Spine. 2003;28(13):1461-1466.

87. Che X, Robin C, Sungwook C, Paul BF, Bernadette MF. Investigating the influence of social support on experimental pain and related physiological arousal: A systematic review and meta-analysis. Neuroscience \& Biobehavioral Reviews. 2018;92:437-452.

88. Lamé IE, Peters ML, Vlaeyen JW, Kleef Mv, Patijn J. Quality of life in chronic pain is more associated with beliefs about pain, than with pain intensity. European Journal of Pain. 2005;9(1):15-24.

This article is protected by copyright. All rights reserved 
89. Karayannis NV, Baumann I, Sturgeon JA, Melloh M, Mackey SC. The impact of social isolation on pain interference: A longitudinal study. Annals of Behavioral Medicine. 2018;53(1):65-74.

90. Dagenais S, Caro J, Haldeman S. A systematic review of low back pain cost of illness studies in the United States and internationally. The Spine Journal. 2008;8(1):8-20.

91. Costa LdCM, Maher CG, McAuley JH, et al. Prognosis for patients with chronic low back pain: Inception cohort study. The BMJ. 2009;339:1-8.

92. Schofield DJ, Shrestha RN, Percival R, Callander EJ, Kelly SJ, Passey ME. Early retirement and the financial assets of individuals with back problems. European Spine Journal. 2011;20(5):731-736.

93. Niv D, Kreitler S. Pain and quality of life. Pain Practice 2001;1(2):150-161.

94. Kovacs FM, Abraira V, Zamora J, Fernández C. The transition from acute to subacute and chronic low back pain: A study based on determinants of quality of life and prediction of chronic disability. Spine. 2005;30(15):1786-1792.

95. Scholich SL, Hallner D, Wittenberg RH, Hasenbring MI, Rusu AC. The relationship between pain, disability, quality of life and cognitive-behavioural factors in chronic back pain. Disability and Rehabilitation. 2012;34(23):1993-2000.

96. Ware Jr JE, Sherbourne CD. The MOS 36-item short-form health survey (SF-36): Conceptual framework and item selection. Medical Care. 1992:473-483.

97. Machado GC, Pinheiro MB, Lee H, et al. Smartphone apps for the self-management of low back pain: A systematic review. Best Practice \& Research Clinical Rheumatology. 2016;30(6):1098-1109.

98. Middelweerd A, Mollee JS, van der Wal CN, Brug J, Te Velde SJ. Apps to promote physical activity among adults: A review and content analysis. International Journal of Behavioral Nutrition and Physical Activity. 2014;11(1):97.

99. Mateo GF, Granado-Font E, Ferré-Grau C, Montaña-Carreras X. Mobile phone apps to promote weight loss and increase physical activity: A systematic review and meta-analysis. Journal of Medical Internet Research. 2015;17(11):e253.

This article is protected by copyright. All rights reserved 
100. Azar KM, Lesser LI, Laing BY, et al. Mobile applications for weight management: Theorybased content analysis. American Journal of Preventive Medicine. 2013;45(5):583-589.

101. Torous J, Powell AC. Current research and trends in the use of smartphone applications for mood disorders. Internet Interventions. 2015;2(2):169-173.

102. Ko P-RT, Kientz JA, Choe EK, Kay M, Landis CA, Watson NF. Consumer sleep technologies: A review of the landscape. Journal of Clinical Sleep Medicine. 2015;11(12):1455-1461.

103. Areán PA, Ly KH, Andersson G. Mobile technology for mental health assessment. Dialogues in Clinical Neuroscience. 2016;18(2):163.

104. Slade SC, Molloy E, Keating JL. Listen to me, tell me': A qualitative study of partnership in care for people with non-specific chronic low back pain. Clinical Rehabilitation. 2009;23(3):270-280.

105. Gatchel RJ, McGeary DD, McGeary CA, Lippe B. Interdisciplinary chronic pain management: past, present, and future. American Psychologist. 2014;69(2):119.

106. Varady K. Intermittent versus daily calorie restriction: Which diet regimen is more effective for weight loss? Obesity Reviews. 2011;12(7):593-601.

107. Fairbank JC, Pynsent PB. The Oswestry disability index. Spine. 2000;25(22):2940-2953.

108. Roland M, Morris R. A study of the natural history of back pain. Part 1: Development of a reliable and sensitive measure of disability in low-back pain. Spine. 1983;8(2):141-144.

109. Vianin M. Psychometric properties and clinical usefulness of the Oswestry Disability Index. Journal of Chiropractic Medicine. 2008;7(4):161-163.

110. Chiarotto A, Maxwell LJ, Terwee CB, Wells GA, Tugwell P, Ostelo RW. Roland-Morris Disability Questionnaire and Oswestry Disability Index: Which has better measurement properties for measuring physical functioning in nonspecific low back pain? Systematic review and meta-analysis. Physical Therapy. 2016;96(10):1620-1637.

111. Gomes-Neto M, Lopes JM, Conceição CS, et al. Stabilization exercise compared to general exercises or manual therapy for the management of low back pain: A systematic review and meta-analysis. Physical Therapy in Sport. 2017;23:136-142.

This article is protected by copyright. All rights reserved 
112. Searle A, Spink M, Ho A, Chuter V. Exercise interventions for the treatment of chronic low back pain: A systematic review and meta-analysis of randomised controlled trials. Clinical Rehabilitation. 2015;29(12):1155-1167.

113. Rubinstein SM, de Zoete A, van Middelkoop M, Assendelft WJ, de Boer MR, van Tulder MW. Benefits and harms of spinal manipulative therapy for the treatment of chronic low back pain: Systematic review and meta-analysis of randomised controlled trials. The BMJ. 2019;364:689.

114. Vibe Fersum K, O'Sullivan P, Skouen J, Smith A, Kvåle A. Efficacy of classification - based cognitive functional therapy in patients with non - specific chronic low back pain: A randomized controlled trial. European Journal of Pain. 2013;17(6):916-928.

115. Hockings RL, McAuley JH, Maher CG. A systematic review of the predictive ability of the Orebro Musculoskeletal Pain Questionnaire. Spine. 2008;33(15):494-500.

116. Opsommer E, Hilfiker R, Raval-Roland B, Crombez G, Rivier G. Test-retest reliability of the Örebro Musculoskeletal Pain Screening Questionnaire and the Situational Pain Scale in patients with chronic low back pain. Swiss Medical Weekly. 2013;143(4950).

117. Johnston V. Örebro musculoskeletal pain screening questionnaire. Australian Journal of Physiotherapy. 2009;55(2):141.

118. Bruyère $\mathrm{O}$, Demoulin $\mathrm{M}$, Beaudart $\mathrm{C}$, et al. Validity and reliability of the French version of the STarT Back screening tool for patients with low back pain. Spine. 2014;39(2):E123-E128.

119. Ito T, Shirado O, Suzuki H, Takahashi M, Kaneda K, Strax TE. Lumbar trunk muscle endurance testing: An inexpensive alternative to a machine for evaluation. Archives of Physical Medicine and Rehabilitation. 1996;77(1):75-79.

120. Kell RT, Asmundson GJ. A comparison of two forms of periodized exercise rehabilitation programs in the management of chronic nonspecific low-back pain. The Journal of Strength \& Conditioning Research. 2009;23(2):513-523.

121. Kell RT, Risi AD, Barden JM. The response of persons with chronic nonspecific low back pain to three different volumes of periodized musculoskeletal rehabilitation. The Journal of Strength \& Conditioning Research. 2011;25(4):1052-1064.

This article is protected by copyright. All rights reserved 
122. Harding AT, Weeks BK, Horan SA, Little A, Watson SL, Beck BR. Validity and test-retest reliability of a novel simple back extensor muscle strength test. SAGE Open Medicine. 2017;5:1-9.

123. American College of Sports Medicine. ACSM's guidelines for exercise testing and prescription. Lippincott Williams \& Wilkins; 2013.

124. Seo D-i, Kim E, Fahs CA, et al. Reliability of the one-repetition maximum test based on muscle group and gender. Journal of Sports Science \& Medicine. 2012;11(2):221.

125. Andersson EI, Lin CC, Smeets RJ. Performance tests in people with chronic low back pain: responsiveness and minimal clinically important change. Spine. 2010;35(26):E1559-E1563.

126. Smeets RJ, Hijdra HJ, Kester AD, Hitters MW, Knottnerus JA. The usability of six physical performance tasks in a rehabilitation population with chronic low back pain. Clinical Rehabilitation. 2006;20(11):989-997.

127. Shnayderman I, Katz-Leurer M. An aerobic walking programme versus muscle strengthening programme for chronic low back pain: A randomized controlled trial. Clinical Rehabilitation. 2013;27(3):207-214

128. Aasa B, Berglund L, Michaelson P, Aasa U. Individualized low-load motor control exercises and education versus a high-load lifting exercise and education to improve activity, pain intensity, and physical performance in patients with low back pain: A randomized controlled trial. Journal of Orthopaedic \& Sports Physical Therapy. 2015;45(2):77-85.

129. Christiansen S, Oettingen G, Dahme B, Klinger R. A short goal-pursuit intervention to improve physical capacity: A randomized clinical trial in chronic back pain patients. Pain. 2010;149(3):444-452.

130. Ackland TR, Lohman TG, Sundgot-Borgen J, et al. Current status of body composition assessment in sport. Sports Medicine. 2012;42(3):227-249.

131. Sampaio LR, Simões EJ, Assis AMO, Ramos LR. Validity and reliability of the sagittal abdominal diameter as a predictor of visceral abdominal fat. Arquivos Brasileiros de Endocrinologia \& Metabologia. 2007;51(6):980-986.

132. Verweij LM, Terwee CB, Proper KI, Hulshof CT, van Mechelen W. Measurement error of waist circumference: Gaps in knowledge. Public Health Nutrition. 2013;16(2):281-288.

This article is protected by copyright. All rights reserved 
133. Mason C, Katzmarzyk PT. Variability in waist circumference measurements according to anatomic measurement site. Obesity. 2009;17(9):1789-1795.

134. Vlaeyen JW, Kole-Snijders AM, Boeren RG, Van Eek H. Fear of movement/(re) injury in chronic low back pain and its relation to behavioral performance. Pain. 1995;62(3):363-372.

135. Waddell G, Newton M, Henderson I, Somerville D, Main CJ. A Fear-Avoidance Beliefs Questionnaire (FABQ) and the role of fear-avoidance beliefs in chronic low back pain and disability. Pain. 1993;52(2):157-168.

136. George SZ, Valencia C, Beneciuk JM. A psychometric investigation of fear-avoidance model measures in patients with chronic low back pain. Journal of Orthopaedic \& Sports Physical Therapy. 2010;40(4):197-205.

137. Lundberg MK, Styf J, Carlsson SG. A psychometric evaluation of the Tampa Scale for Kinesiophobia-from a physiotherapeutic perspective. Physiotherapy Theory and Practice. 2004;20(2):121-133.

138. Lüning Bergsten C, Lundberg M, Lindberg P, Elfving B. Change in kinesiophobia and its relation to activity limitation after multidisciplinary rehabilitation in patients with chronic back pain. Disability and Rehabilitation. 2012;34(10):852-858.

139. French DJ, France CR, Vigneau F, French JA, Evans RT. Fear of movement/(re) injury in chronic pain: A psychometric assessment of the original English version of the Tampa scale for kinesiophobia (TSK). Pain. 2007;127(1-2):42-51.

140. Ostelo RW, Swinkels-Meewisse IJ, Vlaeyen JW, Knol DL, De Vet HC. Assessing pain and pain-related fear in acute low back pain: What is the smallest detectable change? International Journal of Behavioral Medicine. 2007;14(4):242-248.

141. Watson JA, Cormac RG, Cooper L, et al. Pain neuroscience education for adults with chronic musculoskeletal pain: A mixed-methods systematic review and meta-analysis. The Journal of Pain. 2019; In Press.

142. Monticone M, Ambrosini E, Rocca B, Magni S, Brivio F, Ferrante S. A multidisciplinary rehabilitation programme improves disability, kinesiophobia and walking ability in subjects with chronic low back pain: Results of a randomised controlled pilot study. European Spine Journal. 2014;23(10):2105-2113.

This article is protected by copyright. All rights reserved 
143. Pardo GB, Girbés EL, Roussel NA, Izquierdo TG, Penick VJ, Martín DP. Pain neurophysiology education and therapeutic exercise for patients with chronic low back pain: A single-blind randomized controlled trial. Archives of Physical Medicine and Rehabilitation. 2018;99(2):338-347.

144. Nicholas MK. The pain self-efficacy questionnaire: Taking pain into account. 2007;11(2):153163.

145. Maughan EF, Lewis JS. Outcome measures in chronic low back pain. European Spine Journal. 2010;19(9):1484-1494.

146. Ryan CG, Gray HG, Newton M, Granat MH. Pain biology education and exercise classes compared to pain biology education alone for individuals with chronic low back pain: A pilot randomised controlled trial. Manual Therapy. 2010;15(4):382-387.

147. Sullivan MJ, Bishop SR, Pivik J. The pain catastrophizing scale: development and validation. Psychological assessment. 1995;7(4):524.

148. Meyer K, Sprott H, Mannion AF. Cross-cultural adaptation, reliability, and validity of the German version of the Pain Catastrophizing Scale. Journal of Psychosomatic Research. 2008;64(5):469-478.

149. Henry JD, Crawford JR. The short - form version of the Depression Anxiety Stress Scales (DASS - 21): Construct validity and normative data in a large non - clinical sample. British Journal of Clinical Psychology. 2005;44(2):227-239.

150. Ronk FR, Korman JR, Hooke GR, Page AC. Assessing clinical significance of treatment outcomes using the DASS-21. Psychological Assessment. 2013;25(4):1103.

151. Jackson JK, Shepherd TR, Kell RT. The influence of periodized resistance training on recreationally active males with chronic nonspecific low back pain. The Journal of Strength \& Conditioning Research. 2011;25(1):242-251.

152. Sveinsdottir V, Eriksen HR, Reme SE. Assessing the role of cognitive behavioral therapy in the management of chronic nonspecific back pain. Journal of Pain Research. 2012;5:371-380.

153. Buysse DJ, Reynolds III CF, Monk TH, Berman SR, Kupfer DJ. The Pittsburgh Sleep Quality Index: A new instrument for psychiatric practice and research. Psychiatry Research. 1989;28(2):193-213.

This article is protected by copyright. All rights reserved 
154. Mollayeva T, Thurairajah P, Burton K, Mollayeva S, Shapiro CM, Colantonio A. The Pittsburgh sleep quality index as a screening tool for sleep dysfunction in clinical and nonclinical samples: A systematic review and meta-analysis. Sleep Medicine Reviews. 2016;25:52-73.

155. Tomfohr LM, Schweizer CA, Dimsdale JE, Loredo JS. Psychometric characteristics of the Pittsburgh Sleep Quality Index in English speaking non-Hispanic whites and English and Spanish speaking Hispanics of Mexican descent. Journal of Clinical Sleep Medicine. 2013;9(1):61-66.

156. Tang NK. Cognitive-behavioral therapy for sleep abnormalities of chronic pain patients. Current Rheumatology Reports. 2009;11(6):451.

157. Cook KF, Jensen SE, Schalet BD, et al. PROMIS measures of pain, fatigue, negative affect, physical function, and social function demonstrated clinical validity across a range of chronic conditions. Journal of Clinical Epidemiology. 2016;73:89-102.

158. Purvis TE, Neuman BJ, Riley III LH, Skolasky RL. Discriminant ability, concurrent validity, and responsiveness of PROMIS health domains among patients with lumbar degenerative disease undergoing decompression with or without arthrodesis. Spine. 2018;43(21):15121520.

159. Hahn EA, DeVellis RF, Bode RK, et al. Measuring social health in the patient-reported outcomes measurement information system (PROMIS): Item bank development and testing. Quality of Life Research. 2010;19(7):1035-1044.

160. Monticone M, Ferrante S, Rocca B, Baiardi P, Dal Farra F, Foti C. Effect of a long-lasting multidisciplinary program on disability and fear-avoidance behaviors in patients with chronic low back pain: Results of a randomized controlled trial. The Clinical Journal of Pain. 2013;29(11):929-938.

161. Reilly MC, Zbrozek AS, Dukes EM. The validity and reproducibility of a work productivity and activity impairment instrument. Pharmacoeconomics. 1993;4(5):353-365.

162. Lerner D, Amick III BC, Rogers WH, Malspeis S, Bungay K, Cynn D. The work limitations questionnaire. Medical Care. 2001:72-85.

This article is protected by copyright. All rights reserved 
163. Kool J, de Bie R, Oesch P, Knusel O, van den Brandt P, Bachmann S. Exercise reduces sick leave in patients with non-acute non-specific low back pain: A meta-analysis. Journal of Rehabilitation Medicine. 2004;36:49-62.

164. Ware Jr JE, Kosinski M, Keller SD. A 12-Item short-form health survey: Construction of scales and preliminary tests of reliability and validity. Medical Care. 1996:220-233.

165. Luo X, George ML, Kakouras I, et al. Reliability, validity, and responsiveness of the short form 12-item survey (SF-12) in patients with back pain. Spine. 2003;28(15):1739-1745.

166. Wajswelner H, Metcalf B, Bennell K. Clinical Pilates versus general exercise for chronic low back pain: Randomized trial. Medicine \& Science in Sports \& Exercise. 2012;44(7):11971205.

167. Lohr KN. Assessing health status and quality-of-life instruments: Atributes and review criteria. Quality of Life Research. 2002;11(3):193-205.

168. McHorney CA, Tarlov AR. Individual-patient monitoring in clinical practice: Are available health status surveys adequate? Quality of Life Research. 1995;4(4):293-307.

169. Weir JP. Quantifying test-retest reliability using the intraclass correlation coefficient and the SEM. The Journal of Strength \& Conditioning Research. 2005;19(1):231-240. 
Table 1. Outcomes relevant to consider for the treatment of CLBP in clinical practice.

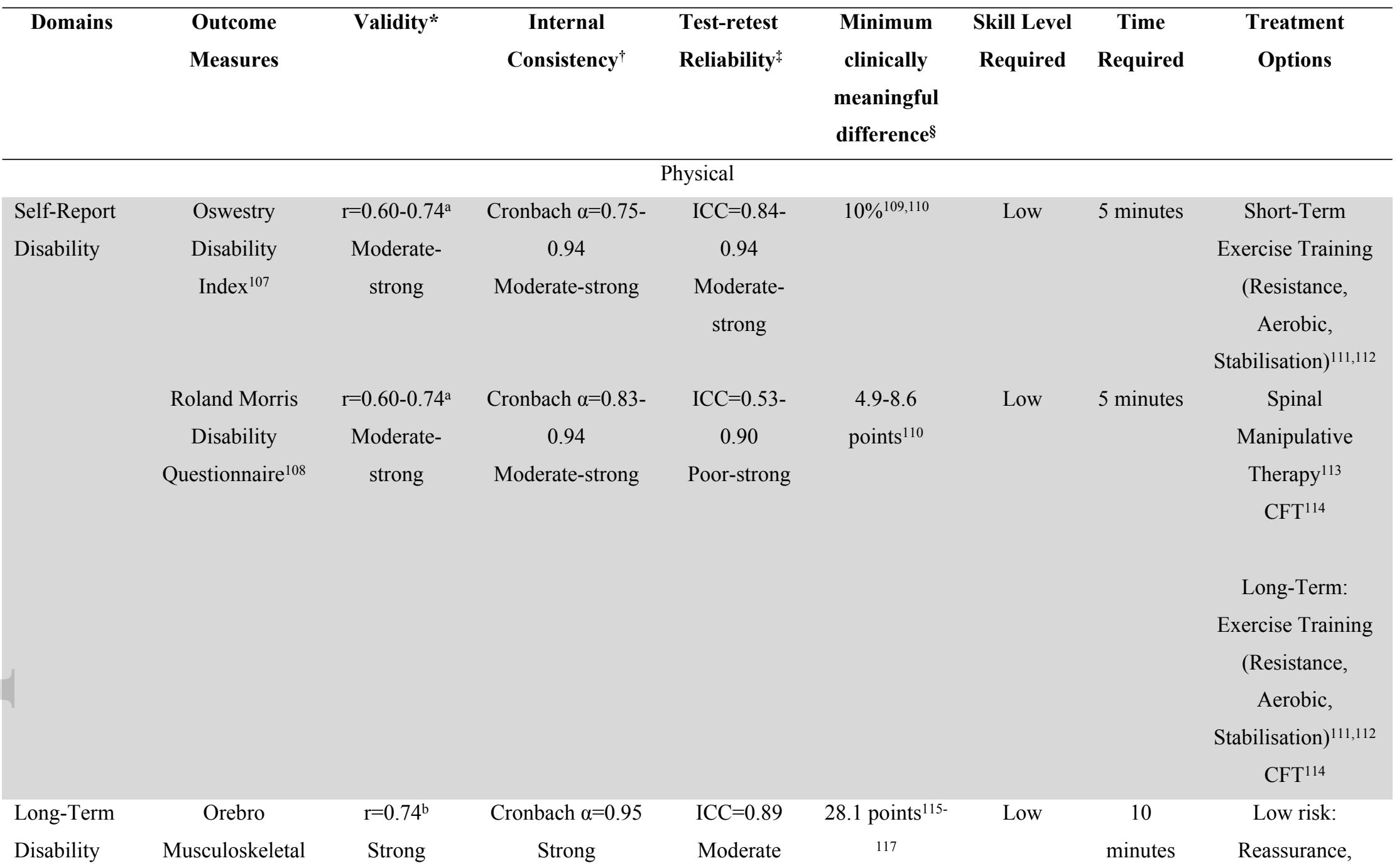

This article is protected by copyright. All rights reserved 


\begin{tabular}{|c|c|c|c|c|c|c|c|c|}
\hline Screening & $\begin{array}{c}\text { Pain } \\
\text { Questionnaire }^{42}\end{array}$ & & & & & & & $\begin{array}{l}\text { Advice and } \\
\text { Education }^{43}\end{array}$ \\
\hline & $\begin{array}{l}\text { Keele STarT } \\
\text { Back Tool }{ }^{43}\end{array}$ & $\begin{array}{l}r=0.74^{b} \\
\text { Strong }\end{array}$ & $\begin{array}{c}\text { Cronbach } \alpha=0.73 \\
\text { Moderate }\end{array}$ & $\begin{array}{c}\mathrm{ICC}=0.90 \\
\text { Strong }\end{array}$ & $\mathrm{NA}^{118}$ & Low & $\begin{array}{c}10 \\
\text { minutes }\end{array}$ & $\begin{array}{c}\text { Medium Risk: } \\
\text { Physiotherapy, } \\
\text { Physical Therapy } \\
\text { and Exercise } \\
\text { Training } \\
\\
\text { High Risk: } \\
\text { Same as medium } \\
\text { risk with the } \\
\text { addition of targeted } \\
\text { psychological } \\
\text { treatment }{ }^{43}\end{array}$ \\
\hline $\begin{array}{l}\text { Trunk } \\
\text { Endurance } \\
\text { Testing }\end{array}$ & $\begin{array}{l}\text { Ito Back Flexion } \\
\text { and Extension } \\
\text { Endurance }^{119}\end{array}$ & NA & Not applicable & $\begin{array}{c}\text { ICC }=0.90- \\
0.97 \\
\text { Strong }\end{array}$ & $\mathrm{NA}^{119}$ & Moderate & $\begin{array}{c}10 \\
\text { minutes }\end{array}$ & $\begin{array}{c}\text { Resistance } \\
\text { Training } \\
\end{array}$ \\
\hline $\begin{array}{l}\text { Trunk } \\
\text { Strength } \\
\text { Testing }\end{array}$ & $\begin{array}{c}\text { Hand Held } \\
\text { Dynamometer } \\
\text { Testing for Back } \\
\text { Extensors }^{122}\end{array}$ & $\begin{array}{l}\mathrm{r}=0.82^{\mathrm{c}} \\
\text { Strong }\end{array}$ & Not applicable & $\begin{array}{c}\mathrm{ICC}=0.90 \\
\text { Strong }\end{array}$ & $\mathrm{NA}^{122}$ & Moderate & 5 minutes & $\begin{array}{c}\text { Resistance } \\
\text { Training }{ }^{120,121}\end{array}$ \\
\hline $\begin{array}{l}\text { Global } \\
\text { Muscle } \\
\text { Strength }\end{array}$ & $\begin{array}{c}\text { Repetition Max } \\
\text { Testing (1- } \\
\text { 10RM })^{123}\end{array}$ & NA & Not applicable & $\begin{array}{c}\text { ICC }=0.91- \\
0.99 \\
\text { Strong }\end{array}$ & $\mathrm{NA}^{124}$ & Moderate & $\begin{array}{c}15 \\
\text { minutes }\end{array}$ & $\begin{array}{c}\text { Resistance } \\
\text { Training }{ }^{120,121}\end{array}$ \\
\hline
\end{tabular}

This article is protected by copyright. All rights reserved 


\begin{tabular}{|c|c|c|c|c|c|c|c|c|}
\hline & $\begin{array}{c}\text { Leg Strength (Leg } \\
\text { Press) } \\
\text { Upper Limb } \\
\text { Strength (Chest } \\
\text { Press) }\end{array}$ & & & & & & & \\
\hline $\begin{array}{l}\text { Performance } \\
\text { Battery } \\
\text { Testing }^{125}\end{array}$ & $\begin{array}{c}\text { Five Minute Walk } \\
\text { Test } \\
\text { Sit-to-Stand Test } \\
\text { Stair Climbing }\end{array}$ & NA & Not applicable & $\begin{array}{c}\text { ICC }=0.74- \\
0.99 \\
\text { Moderate- } \\
\text { strong }\end{array}$ & $19-45 \% \%^{125,126}$ & Moderate & $\begin{array}{c}20 \\
\text { minutes }\end{array}$ & $\begin{array}{c}\text { Exercise } \\
\text { Training }{ }^{127,128} \\
\text { CBT }^{129}\end{array}$ \\
\hline $\begin{array}{l}\text { Body } \\
\text { Composition } \\
130\end{array}$ & $\begin{array}{c}\text { Weight } \\
\text { BMI } \\
\text { Waist } \\
\text { Circumference } \\
\text { Hip } \\
\text { Circumference } \\
\text { Waist-to-Hip } \\
\text { Ratio }\end{array}$ & $\begin{aligned} \mathrm{r}=0.72-0.77^{\mathrm{d}} & \\
& \text { Strong }\end{aligned}$ & Not applicable & $\begin{array}{c}\mathrm{ICC}=0.99 \\
\text { Strong }\end{array}$ & $5 \% 131-133$ & Low & 5 minutes & $\begin{array}{c}\text { Dietary } \\
\text { Intervention }^{106}\end{array}$ \\
\hline \multicolumn{9}{|c|}{ Psychological } \\
\hline $\begin{array}{l}\text { Kinesiophob } \\
\text { ia/Fear } \\
\text { Avoidance }\end{array}$ & $\begin{array}{c}\text { Tampa Scale of } \\
\text { Kinesiophobia }^{134}\end{array}$ & $\begin{array}{c}\mathrm{r}=0.38-0.62^{\mathrm{e}} \\
\text { Moderate }\end{array}$ & $\begin{array}{c}\text { Cronbach } \alpha=0.84 \\
\text { Moderate }\end{array}$ & $\begin{array}{c}\mathrm{ICC}=0.91 \\
\text { Strong }\end{array}$ & 8 points ${ }^{136-139}$ & Low & 5 minutes & $\begin{array}{c}\mathrm{PNE}^{141} \\
\mathrm{CBT}^{142,143} \\
\mathrm{CFT}^{114}\end{array}$ \\
\hline & $\begin{array}{l}\text { Fear-Avoidance } \\
\text { Beliefs } \\
\text { Questionnaire }^{135}\end{array}$ & $\begin{array}{c}\mathrm{r}=0.38-0.62^{\mathrm{e}} \\
\text { Moderate }\end{array}$ & $\begin{array}{c}\text { Cronbach } \alpha=0.77- \\
0.88 \\
\text { Moderate }\end{array}$ & $\begin{array}{c}\text { ICC }=0.90- \\
0.96 \\
\text { Strong }\end{array}$ & $\begin{array}{c}\text { 9.4-12.7 } \\
\text { points }{ }^{135,136,140}\end{array}$ & Low & 5 minutes & \\
\hline Pain Self- & Pain Self-Efficacy & $\mathrm{r}=0.64-0.85$ & Cronbach $\alpha=0.92$ & $\mathrm{ICC}=0.92$ & 8 points $^{72,145}$ & Low & 5 minutes & Exercise \\
\hline
\end{tabular}

This article is protected by copyright. All rights reserved 


\begin{tabular}{|c|c|c|c|c|c|}
\hline Efficacy & Questionnaire $^{144}$ & $\begin{array}{c}\text { Moderate- } \\
\text { strong }\end{array}$ & Strong & Strong & $\begin{array}{c}\text { Training }{ }^{146} \\
\text { PNF}^{146}\end{array}$ \\
\hline
\end{tabular}

\begin{tabular}{|c|c|c|c|c|c|c|c|c|}
\hline $\begin{array}{l}\text { Pain } \\
\text { Catastrophiz } \\
\text { ing }\end{array}$ & $\begin{array}{c}\text { Pain } \\
\text { Catastrophizing } \\
\text { Scale }^{147}\end{array}$ & $\begin{array}{c}\mathrm{r}=0.31-0.61^{\mathrm{f}} \\
\text { Moderate }\end{array}$ & $\begin{array}{c}\text { Cronbach } \alpha=0.87 \text { - } \\
0.92 \\
\text { Moderate-strong }\end{array}$ & $\begin{array}{c}\text { ICC }=0.80- \\
0.93 \\
\text { Moderate- } \\
\text { strong }\end{array}$ & $\mathrm{NA}^{136,148}$ & Low & 5 minutes & $\begin{array}{l}\mathrm{PNE}^{141} \\
\mathrm{CBT}^{142}\end{array}$ \\
\hline $\begin{array}{l}\text { Depression } \\
\text { and Anxiety }\end{array}$ & $\begin{array}{c}\text { Depression } \\
\text { Anxiety Stress } \\
\text { Scale }(21 \text {-item })^{149}\end{array}$ & $\begin{array}{c}\mathrm{r}=0.40-0.69^{\mathrm{g}} \\
\text { Moderate }\end{array}$ & $\begin{array}{c}\text { Cronbach } \alpha=0.93 \\
\text { Strong }\end{array}$ & $\begin{array}{c}\text { ICC }=0.82- \\
0.90 \\
\text { Moderate- } \\
\text { strong }\end{array}$ & 5 points $^{149,150}$ & Low & 5 minutes & $\begin{array}{c}\text { Exercise } \\
\text { Training }{ }^{120,121,151} \\
\text { CBT }^{152}\end{array}$ \\
\hline $\begin{array}{l}\text { Sleep } \\
\text { Quality }\end{array}$ & $\begin{array}{l}\text { Pittsburgh Sleep } \\
\text { Quality Index }{ }^{153}\end{array}$ & $\begin{aligned} \mathrm{r}=0.72-0.80^{\mathrm{h}} & \\
& \text { Strong }\end{aligned}$ & $\begin{array}{c}\text { Cronbach } \alpha=0.70- \\
0.83 \\
\text { Moderate }\end{array}$ & $\begin{array}{c}\mathrm{ICC}=0.70- \\
0.86 \\
\text { Moderate }\end{array}$ & $\mathrm{NA}^{154,155}$ & Low & 5 minutes & $\mathrm{CBT}^{156}$ \\
\hline \multicolumn{9}{|c|}{ Social } \\
\hline $\begin{array}{l}\text { Social } \\
\text { Functioning }\end{array}$ & $\begin{array}{l}\text { PROMIS Social } \\
\text { Functioning }{ }^{157}\end{array}$ & $\begin{array}{c}\mathrm{r}=0.45-0.51^{\mathrm{i}} \\
\text { Moderate }\end{array}$ & $\begin{array}{c}\text { Cronbach } \alpha=0.98 \\
\text { Strong }\end{array}$ & NA & $\mathrm{NA}^{158,159}$ & Low & 5 minutes & $\begin{array}{c}\text { Exercise } \\
\text { Training }{ }^{120,121,151} \\
\text { CBT }^{142,160} \\
\text { CFT }^{114}\end{array}$ \\
\hline $\begin{array}{l}\text { Work } \\
\text { Absenteeism }\end{array}$ & $\begin{array}{c}\text { Work } \\
\text { Productivity and } \\
\text { Activity } \\
\text { Impairment }\end{array}$ & $\begin{array}{c}\mathrm{r}=0.54-0.64 \mathrm{j} \\
\text { Moderate }\end{array}$ & $\begin{array}{c}\text { Cronbach } \alpha=0.88- \\
0.96 \\
\text { Moderate-strong }\end{array}$ & $\begin{array}{c}\mathrm{ICC}=0.80- \\
0.84 \\
\text { Moderate }\end{array}$ & $\mathrm{NA}^{161,162}$ & Low & 5 minutes & $\begin{array}{c}\text { Exercise } \\
\text { Training }{ }^{163} \\
\text { CFT }^{114}\end{array}$ \\
\hline
\end{tabular}

This article is protected by copyright. All rights reserved 


\begin{tabular}{|c|c|c|c|c|c|c|c|c|}
\hline \multicolumn{9}{|c|}{ Other } \\
\hline Health- & SF-12 164 & RV & Cronbach $\alpha=0.77$ & $\mathrm{r}=0.84-0.91$ & 6 points $^{164,165}$ & Low & 10 & Exercise Training \\
\hline related & & coefficient $=$ & 0.80 & Moderate- & & & minutes & (Resistance, \\
\hline Quality of & & $0.64-0.97$ & Moderate & strong & & & & Aerobic, \\
\hline \multirow[t]{3}{*}{ Life } & & Moderate- & & & & & & Stabilisation) $)^{120,121,}$ \\
\hline & & strong & & & & & & 151,166 \\
\hline & & & & & & & & $\mathrm{CBT}^{31,142,160}$ \\
\hline
\end{tabular}

$\mathrm{BMI}=$ body mass index, $\mathrm{CBT}=$ cognitive behavioural therapy, $\mathrm{CFT}=$ cognitive functional therapy, ICC $=$ intraclass correlation coefficient, LBP $=$ low back pain, NA = not available, PNE = pain neuroscience education, PROMIS = Patient Reported Outcomes Measurement Information System *Validity: correlations of $>0.7$ are strong, $0.3-0.7$ are moderate and $<0.3$ are weak. ${ }^{167} \uparrow$ Internal consistency: For groups Cronbach $\alpha \geq 0.70$ suggested (moderate), for individuals Cronbach $\alpha \geq 0.90$ suggested (strong). ${ }^{154} \ddagger$ Test-retest reliability: For groups ICC $\geq 0.70$ suggested (moderate), for individuals ICC $\geq 0.90$ suggested (strong). ${ }^{168} \$$ Minimum clinically meaningful difference is how large a difference needs to be present in a single patient for it to be "real". 169

${ }^{a}$ Constuct validity between Oswestry Disability Index and Roland Morris Disability Questionnaire, ${ }^{b}$ Construct validity between the two long term-disability measures, ${ }^{c}$ Construct validity compared to isokinetic back extensor dynamometry, ${ }^{d}$ Validity of waist circumference and waist-to-hip ratio comparative to visceral adipose fat measured by computed tomography, ${ }^{\mathrm{e} C o n s t r u c t}$ validity between the Tampa Scale of Kinesiophobia and Fear-Avoidance beliefs questionnaire, ${ }^{\mathrm{f} C o n s t r u c t}$ validity determined against measures including the Roland Morris, Pain Intensity and Fear-Avoidance beliefs questionnaire,

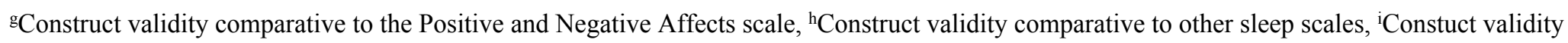
compared to physical and mental composite scores of the SF-12, ${ }^{\mathrm{j}}$ Construct validity compared to interviewer methods.

This article is protected by copyright. All rights reserved 


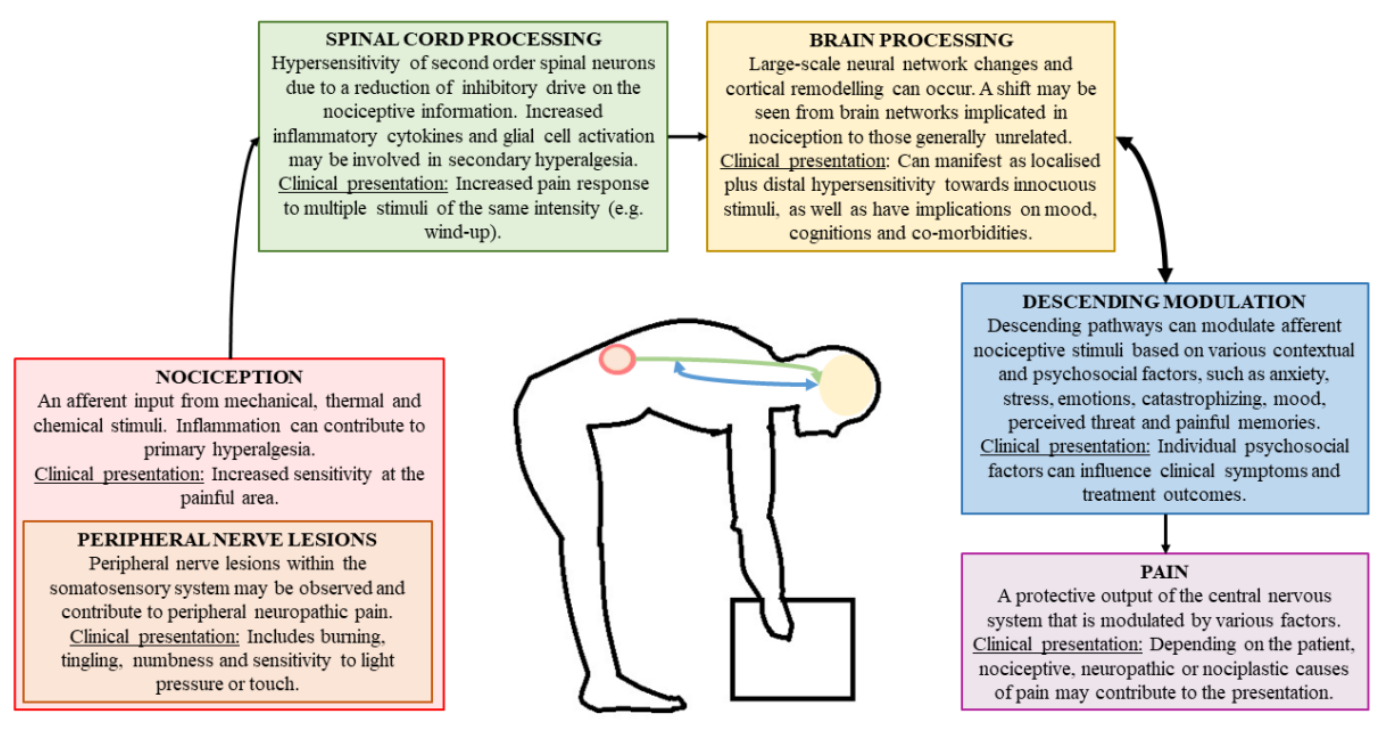

papr_12846_f1.tif 


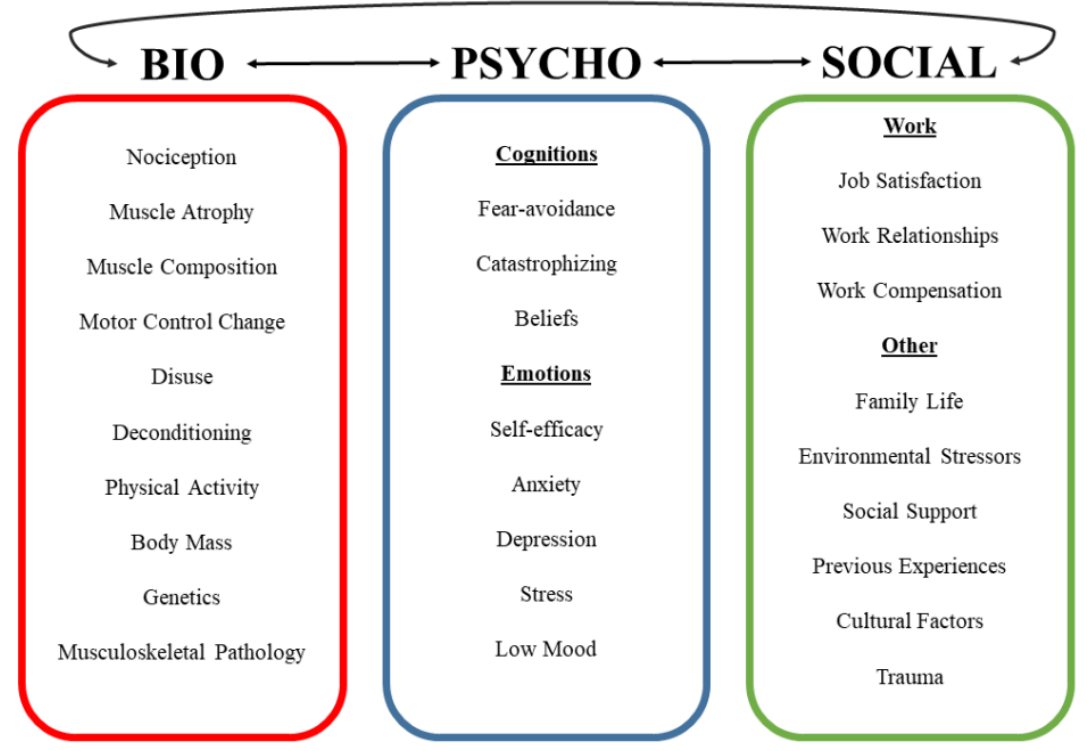

papr_12846_f2.tif 